\title{
Marilia Marchetti, "Médée la barbare" di Catulle Mendès, in Magia, gelosia, vendetta. Il mito di Medea nelle lettere francesi
}

\section{Mario Richter}

\section{(2) OpenEdition \\ Journals}

Edizione digitale

URL: https://journals.openedition.org/studifrancesi/26678

DOI: $10.4000 /$ studifrancesi.26678

ISSN: 2421-5856

\section{Editore}

Rosenberg \& Sellier

\section{Edizione cartacea}

Data di pubblicazione: 1 avril 2007

Paginazione: 206

ISSN: 0039-2944

\section{Notizia bibliografica digitale}

Mario Richter, «Marilia Marchetti, "Médée la barbare" di Catulle Mendès, in Magia, gelosia, vendetta. II mito di Medea nelle lettere francesi», Studi Francesi [Online], 151 (LI | I) | 2007, online dal 30 novembre 2015, consultato il 23 novembre 2021. URL: http://journals.openedition.org/studifrancesi/26678; DOI: https://doi.org/10.4000/studifrancesi.26678

Questo documento è stato generato automaticamente il 23 novembre 2021.

\section{cc) $($ ) $\ominus$}

Studi Francesi è distribuita con Licenza Creative Commons Attribuzione - Non commerciale - Non opere derivate 4.0 Internazionale. 


\title{
Marilia Marchetti, "Médée la barbare" di Catulle Mendès, in Magia, gelosia, vendetta. Il mito di Medea nelle lettere francesi
}

\author{
Mario Richter
}

\section{NOTIZIA}

MARILIA MARChETTI, "Médée la barbare" di Catulle Mendès, in Magia, gelosia, vendetta. Il mito di Medea nelle lettere francesi, a cura di Liana Nissim e Alessandra Preda, Milano, Cisalpino, 2006, pp. 247-262.

1 Attraverso un esame della pièce di Mendès (rappresentata il 28 ottobre 1898 e salutata con entusiasmo dalla critica) è qui osservata nel suo rapporto con la comprensione del mito letterario nel secondo Ottocento, nella specificità del personaggio mitico adottato e infine nelle motivazioni profonde che portano al "degrado del principio eroico". Queste le osservazioni conclusive: "La Médée di Catulle Menès, raramente citata dalla critica compie [...] un percorso che inizia in terra di Colchide; terra barbara, ma terra dell'oro e dell'ambra, terra della luce, che dirige il suo implacabile splendore sull'opacità del mondo greco. Il personaggio di Medea frantuma così il cerchio tautologico delle misere leggi umane, per aprire al terrore imprevedibile della giustizia divina, poiché solo gli dèi danno un destino agli uomini". 